\title{
Perception and Constraints faced by Pulse Growers and yield gap analysis of Green Gram (Vigna radiata L.) in East and South East Coastal Plain of Odisha, India
}

\author{
S.R. Dash ${ }^{1 *}$, B.K. Rautaray ${ }^{1}$ and A. Dhal ${ }^{2}$ \\ ${ }^{1}$ Krishi Vigyan Kendra, Jagatsinghpur, Odisha, India \\ ${ }^{2}$ AICRP, OUAT, Bhubaneswar, Odisha, India \\ *Corresponding author
}

\begin{abstract}
A B S T R A C T
\section{Keywords}

Cluster demonstration,

Technology gap,

Extension gap,

Technology index and

benefit cost ratio

Article Info

Accepted:

04 December 2017

Available Online:

10 January 2018 income.

\section{Introduction}

Green gram (Vigna radiata L.) commonly known as golden gram is one of the most important short duration pulse crops in India. It ranks third among all the pulse crops grown in India. Contribution of pulses to Indian agriculture and daily life has been tremendous besides being one of the important constituents of our diet. India is the largest producer, consumer and importer of pulses. Pulses are the major sources of dietary protein in the vegetarian diet in our country. Besides being a rich source of protein, they maintain
\end{abstract}

The present study was conducted by KVK, Jagatsinghpur during 2016-17 in the rabi seasons with sixty numbers frontline demonstrations across in two clusters of Bagoi village in kujanga block of district Jagatsinghpur. The results of demonstrations showed that farmers could increase the Green gram productivity by adopting improved variety and improved production technology. From the front line demonstrations, it was observed that the improved Green gram variety IPM-02-14recorded the higher yield $(748 \mathrm{~kg} / \mathrm{ha})$ compared to the farmers' practices variety $(553 \mathrm{~kg} / \mathrm{ha})$. The increase in the demonstration yield over farmer's practices was $35 \%$. Technology gap and the technology index values were $352 \mathrm{~kg} / \mathrm{ha}$ and $32 \%$, respectively. The increment in yield of green gram crop under front line demonstrations was due to spreading of improved and latest technology viz. YVM resistance variety Hence, the existing local variety (Jhain mung) can be replaced by HYV, IPM 02-14 since it fits to the existing farming situation for higher productivity and soil fertility through biological nitrogen fixation in soil and thus play a vital role in sustainable agriculture. Pulses are a good and chief source of protein for a majority of the Indian population. Pulses contribute $11 \%$ of the total intake of proteins in India (Reddy, 2010). In India, frequency of pulses consumption is much higher than any other source of protein, which indicates the importance of pulses in their daily food habits. The domestic production of pulses was around 18.1 million tonnes over the last three years. Pulses production in India has not kept up with growth in demand calling for import to 
the tune of 2.0 to 4.0 million tones (Raj et al., 2013). Even though pulses production increased significantly during the last decade but continuing the rapid growth is a challenge for researchers, extension agencies and policy makers to fulfill the domestic demand. The productivity of pulses in India $(694 \mathrm{~kg} / \mathrm{ha})$ is lower than most of the major pulse Green gram gives low seed yield mainly due to poor management and low soil fertility. Green gram or mung bean is the third most important food legumes grown and consumed in India and is a good source of proteins and minerals and its protein quality is similar to or better than other legumes (Kataria et al., 1989). It is consumed in different ways as dal, halwa, snack and so many other preparations. Ascorbic acid (Vitamin C) is synthesized in sprouted seeds of greengram with increment in riboflavin and thiamine. It is also used as green manure crop. Being a short duration crop it also provides an excellent green fodder to the animals. It fits well in various multiple and intercropping systems. The seeds are highly nutritious with protein content of 23-14\%. In India during the year 2016-17 the total pulse area was 238.56 lakh ha with production 18.25 million tonnes with productivity $765 \mathrm{~kg} \mathrm{ha}^{-1}$. India is the largest producer and consumer of pulse in the world, accounting for 25 percent of global production and 15 percent consumption (Saraswati et al., 2004). Green gram is one of the important short season grain legumes in the conventional farming system of tropical and temperate regions. It can be grown on a variety of soil and climatic conditions, as it is tolerant to drought (Malik et al., 2006). When mung bean is grown Green gram or mung bean is the major pulse crop of the state Odisha covering total area of 8.36 lakh ha with average productivity $434 \mathrm{~kg}$ per ha, which is about 40 percent of the total pulse area of the state and in coastal belt green gram and black gram are the major pulse. The district of Jagatsinghpur lies in the agroclimatic zone of east and south east coastal plain zone of Odisha extending from $20-21^{0}$ North latitude to $84-87^{\circ}$ East longitude. The district consists of eight blocks i.e. Jagatsinghpur, Raghunathapur, Balikuda, Biridi, Naugaon, Tirtol, Kujanga and Erasama. The green gram is the major pulse grown in all the eight blocks of the district Jagatsinghpur only in rabi season under residual moisture condition after harvest of Kharif paddy.It is primarily grown under rain fed condition and in a low fertility neglected soil under marginal and sub marginal conditions without any inputs. Residual soil moisture are fully utilized by the farmers in the fields for cultivation of pulse crops. Including mung bean in the rice rotation system has diversified and strengthened the cropping system, alleviated the disadvantage of cereal - cereal cropping system and improved the productivity of the soil and the income of the farmer (Weinberger, 2003). Green gram is cultivated as major pulse crop in all the eight blocks of the district comprising total area of 38000 ha with productivity of $462 \mathrm{~kg} \mathrm{ha}^{-1}$ which is very low as compared to national and state average.

Font line demonstrations are a concept of field demonstrations evolved by in Indian Council of Agriculture and Research (ICAR) during the inception of Technology Mission on Oilseed crops during mid-eighties. The field demonstrations conducted under close supervision of scientists of the National agricultural Research System is called front line demonstration because the technologies are demonstrated for the first time by the scientist themselves before being fed into the main extension system of the state department of agriculture (Venkatasubramanian et al., 2009). The main objective of front line demonstrations is to demonstrate newly released crop production technologies and its management practices in the farmers' field under different farming situations and at different agro-climatic regions. The newly and innovative technology having higher 
production potential under the specific cropping system can be popularized through front line demonstrations programme. These demonstrations are carried out under the supervision of agricultural scientists and the seeds of high yielding var IPM -02-14 and other critical inputs were provided to the farmers by KVK.

\section{Constraints in green gram production in the district}

\section{Biological}

The biological constraints include indeterminate growth habit of local cultivators i.e. Jhain Mung, unproductive plant type, flower and pod shedding, low harvesting index and shattering habit.

\section{Agro ecological}

The crop is mainly cultivated as rain fed crop under marginal and sub marginal conditions without any nutrient management. Generally the farmers are not adopting any nutrient and biofertilizer application and YMV is the major reason for poor yield in this area. As the crop is grown in residual soil moisture, the crop faces water stress condition many times. One of the major constraints of poor yield and spread of green gram, is the non-availability of suitable high yielding variety to replace the traditional varieties. Insufficient extension activities is the major factor resulting in nonadopting of integrated production technology and improved crop management practices developed at research institutions. Replacement ratio of local cultivar with HYV and quality seed is very poor.

\section{Socio-economic}

Although there have been markedly increase in price, even then green grams remain poor competitors to cereals, oilseeds and other cash crops due to yield instability, high loses in storage and lack of facility for post-harvest management like processing, as compared to other crops. As the crop is grown in neglected lands under residual soil moisture with poor management practices, the crop faces water stress condition many times leading to decrease in productivity and profitability.

\section{Objectives}

The present investigation was under taken for assessing the performance along with yield attributing parameters and economic of return of HYV green gram variety IPM 02-14 in coastal plain zone of Jagtsinghpur district in compression with farmers local cultivar (Jhain mung), The present study has been undertaken to evaluate the difference between demonstrated technologies vis-a-vis practices followed by the local farmers in green gram crop.

\section{Methodology}

The study was carried out in operational area of Krishi Vigyan Kendra (KVK), Jagatsinghpur during rabi 2016-17. The study was under taken in Kujanga block of Jagatsinghpur district of Odisha and the block was selected purposefully as green gram is the major crop in rabi season. The geographic location of the area Longitute-86-34'33.9" E, Latitude20-19'34.6" N.

Before conducting demonstration a list of 60 farmers was prepared by conducting group meeting and specific skill training was imparted to the selected farmers regarding improved crop management aspects. Sixty numbers front line demonstrations were conducted in two clusters of green gram crop in comprising sixty number of progressive farmers. All the participating farmers were trained on various aspects of green gram production technologies and Recommended 
agronomic practices and genuine seeds of green gram var IPM -02-14 were used for demonstration. The total area demonstrated was 24.0 ha and plot area of individual farmer was 0.4 ha. The soil of demonstration site was slightly acidic in reaction ( $\mathrm{pH}-6.70)$ with sandy loam in texture and EC was 0.68 (dS $\mathrm{m}^{-1}$ ). The available nitrogen, phosphorus and potassium was between 347.00, 45.00, 364.00 $\left(\mathrm{Kg} \mathrm{ha}^{-1}\right)$ respectively. The crop was sown in residual soil moisture condition in the second week of January with lifesaving irrigation at 30DAS. The crop was raised with recommended agronomic practices and harvested within $4^{\text {th }}$ week of March upto $1^{\text {st }}$ week of April.

KVK Jagatsinhpur conducted front line demonstration with following technologies in cluster approach in Kujanga block the technologies demonstrated were as follows:

Popularization of high yielding green gram variety IPM -02-14

Seed inoculation with biofrtiliser

Line sowing, soil test based fertilizer application

Use of yellow sticky trap for management of white fly and YMV

Need based plant protection measures for sucking pest and pod borers

Foliar spray of Bio Vita and Humic acid 2ml /lit at 30DAS

The field was ploughed two times and planking was done after each ploughing, then seeds were inoculated with Rhizobium culture @ 20.0 gm per $\mathrm{kg}$ seed, and sown in line by using seed cum fertilizer drill with spacing $20 \mathrm{x} 10 \mathrm{~cm}$. and seed rate was $20 \mathrm{~kg} / \mathrm{ha}$. Need based plant protection measures were taken against pod borer and YMV infestation. Soil application of PSB @ $5 \mathrm{~kg} / \mathrm{ha}$, along with soil test based fertiliser application was done with Fertilizer dose NPK - 20:40:20 kg./ha Spraying of Thiomethoxam @ 165gm/Ha for sucking pest management, spraying of Chloropyriphos and Cypermethrin $2 \mathrm{ml} / \mathrm{lit}$ for pod borer control and Foliar spray of Bio Vita and Humic acid $2 \mathrm{ml} / \mathrm{lit}$ at 30DAS was followed along with Installation of yellow sticky Trap @ 20 nos./ha for management of white fly and YMV. In case of local checks existing practices being used by farmers were followed. The observations were recorded for various parameters of the green gram crop. The farmers' practices were maintained in case of local checks. The field observations were taken from demonstration plot and farmers plot as well. Parameters like Plant height, number of pods plant ${ }^{-1}$, pod length, number of seeds pod $^{-1}, 100$ seed weight, Stover yield and grain yield were recorded at maturity stage and the gross returns ( $\mathrm{Rs} \mathrm{ha}^{-1}$ ) were calculated on the basis of prevailing market price of the produce. The extension gap, technology gap, technology index along with $\mathrm{B}$ : $\mathrm{C}$ ratio was calculated the data were statistically analyzed applying the statistical techniques. To estimate the technology gap, extension gap and technology index following formulae have been used:

Technology gap = Pi (Potential yield $)-\mathrm{Di}$ (Demonstration yield)

Extension gap $=$ Di $($ Demonstration Yield $)-F i$ (Farmers yield)

Technology index = $\frac{\text { Technology gap }}{\text { Potential yield }}$

\section{Popularization of high yielding}

High yielding green gram variety IPM -02-14 resistant to Yellow Mosaic Virus was taken 
for demonstration and the certified seed were procured from Odisha State Seed Corporation Ltd, Bhubaneswar. This var IPM -02-14 was released from IIPR, Kanpur in the year 2010. It is developed from cross IPM99-125 x Pusa bold 2. It is Suitable for spring and summer season and resistance to YMV. Its duration is 60-65 days and average yield $1100 \mathrm{~kg} / \mathrm{ha}$

\section{Seed treatment with Rhizobium}

Rhizobium is a root modulating bacteria. It fixes the atmospheric nitrogen to available form in root nodules. Rhizobium also secrets some growth regulators that will be responsible for increasing in yield.

\section{Soil test based fertilizer application}

The fertilizer application was done in the demonstration plots as per the soil test based recommendation. The recommended dose of fertilizer followed for green gram was 20:40:40 N: P: K kg ha ${ }^{-1}$.

As application of ' $\mathrm{P}$ ' is quite effective in increasing the seed yield in green gram. Soil application of PSB @ $5 \mathrm{~kg} / \mathrm{ha}$, along with soil test based fertiliser application was done with Fertilizer dose NPK - 20:40:20 kg/ha.

\section{Foliar application of bio vita and humic acid}

All critical inputs like seed, biofetiliser and humic acid were supplied to the farmers under demonstration programme. Foliar spray of Bio Vita and Humic acid $2 \mathrm{ml} /$ lit was done 30DAS.

\section{Plant protection measures}

Spraying of Thiomethoxam @ 165gm/ha for sucking pest management and spraying of Chloropyriphos and Cypermethrin $2 \mathrm{ml} / \mathrm{lit}$ for pod borer management was demonstrated.
Installation of yellow sticky Trap @ 20 nos./ha for management of white fly and YMV was also practised in demonstration plots.

\section{Results and Discussion}

\section{Differences between farmers' practices and Technology demonstrated}

The major differences were observed between demonstration package and farmer's practices are regarding recommended varieties, seed treatment, time of sowing, fertilizer dose, method of fertilizer application and plant protection measures. Table 1 shows that under the demonstrated plot only recommended variety and bio-fertilizers and yellow sticky traps and need based plant protection chemicals, growth regulators like Humic acid and Biovita were given to farmer by the KVK and all the other package and practices were timely performed by the farmer.

It is also observed that under farmer situation, normally sowing of green gram is earlier to escape from water shortage for irrigation, thus leading to reduction in yield. Regarding the method of fertilization, under demonstration, all fertilizers were applied at the time of sowing, whereas, under farmers' practice, broadcast method of fertilization was adopted. Similar findings have also been observed by Raj et al., (2013).

The data on crop growth parameters as reported in Table 2 indicated that the average plant height, no of branches per plant, local variety were recorded higher than IPM-02-14. The parameters like no of pods per pant, 100 seed wt. (gm) and pod length $(\mathrm{cm})$ was recorded more in case of IPM-02-14 over local check. The variety IPM-02-14, produced 35 percent more seed yield than local check. The reason may be attributed to the genetic variability and varietal difference and 
environmental adoptability. Maximum Stover's yields was obtained from variety IPM-02-14 owing to high dry matter accumulation whereas the local Jhain Mung produced least stover's yield $1852 \mathrm{~kg}$ per ha.

\section{The performance of FLD programme on} production and economics of green gram

A comparison of yield performance between demonstrated practices and local checks is shown in the table 3 .

It is inferred from the table that the seed yield of green gram variety (IPM -02-14) under demonstration was significantly higher (748 $\mathrm{Kg} \mathrm{ha}{ }^{-1}$ ) than local cultivar under farmers practice $\left(553 \mathrm{Kg} \mathrm{ha}^{-1}\right)$. The demonstration yield recorded $35.2 \%$ higher than the yield in case of farmers' practices. However more variations in yield was recorded in farmers practices as compared to demonstration. Similar yield enhancement in different crops in front line demonstration has been documented by Raj et al., (2013). It is evident from the results that the yield of improved YVM resistance variety was found better than the local check under same environment conditions. Farmers were motivated by results of demonstrated agro technologies applied in the FLDs and it is anticipated that they would adopt these technologies in future.

Yield of the front line demonstration and potential yield of the crop was compared to estimate the yield gaps which were further categorized into technology index.

Table.1 Differences between farmers' practices and technological intervention for Green gram crop

\begin{tabular}{|l|l|l|l|}
\hline SI no & Particular & Farmers' Practice & Demonstrated Technology \\
\hline $\mathbf{1}$ & Variety & $\begin{array}{l}\text { Local Green gram } \\
\text { (local Jhain Mung/Kala Mung) }\end{array}$ & $\begin{array}{l}\text { IPM -02-14 } \\
\text { (Average Potential yield 1100kg/ha) }\end{array}$ \\
\hline $\begin{array}{l}\text { Needs were inoculated with } \\
\text { Rhizobium culture @ 20.0 gm /kg } \\
\text { seed }\end{array}$ \\
\hline $\mathbf{3}$ & $\begin{array}{l}\text { Time and } \\
\text { method of } \\
\text { sowing }\end{array}$ & $\begin{array}{l}\text { Second Week of January } \\
\text { Broad casting }\end{array}$ & $\begin{array}{l}\text { Last week of January to Ist week } \\
\text { Feb } \\
\text { Line sowing by seed com fertilizer } \\
\text { drill }\end{array}$ \\
\hline $\mathbf{4}$ & Fertilizer dose & $\begin{array}{l}\text { Irrational use of nitrogenous } \\
\text { fertilizers and less use of } \\
\text { phosphate fertilizers. }\end{array}$ & $\begin{array}{l}\text { Soil application of PSB @ 5 kg/ha, } \\
\text { along with soil test based fertiliser } \\
\text { application (NPK - 20:40:20 kg./ha) }\end{array}$ \\
\hline $\mathbf{5}$ & $\begin{array}{l}\text { Plant protection } \\
\text { measures }\end{array}$ & $\begin{array}{l}\text { Use of Insecticides like Roger } \\
\text { (Dimethoate) or Imidacloprid } \\
\text { for white fly and YMV }\end{array}$ & $\begin{array}{l}\text { Spraying of Thiomethoxam @ } \\
\text { 165gm/ha for sucking pest } \\
\text { management,and spraying of } \\
\text { Chloropyriphos and Cypermethrin 2 } \\
\text { ml/lit for pod borer management }\end{array}$ \\
\hline $\mathbf{5}$ & Foliar spray & No foliar spray & $\begin{array}{l}\text { Foliar spray of Bio Vita and Humic } \\
\text { acid 2ml /lit at 30DAS. }\end{array}$ \\
\hline $\mathbf{6}$ & $\begin{array}{l}\text { Mechanical pest } \\
\text { control method }\end{array}$ & No use & $\begin{array}{l}\text { Installation of yellow sticky Trap @ } \\
\text { 20 nos./ha for management of white } \\
\text { fly and YMV }\end{array}$ \\
\hline
\end{tabular}


Table.2 Agronomical parameters of green gram observed in farmer's field and demonstration field during Rabi 2016-17

\begin{tabular}{|c|c|c|c|c|c|c|c|c|c|c|c|c|c|}
\hline Treatment & $\begin{array}{l}\text { Mean Plant } \\
\text { Height at } \\
\text { harvest }(\mathrm{cm})\end{array}$ & \multicolumn{2}{|c|}{$\begin{array}{l}\text { No } \\
\text { Branches } \\
\text { plant }^{-1}\end{array}$} & \multicolumn{2}{|c|}{$\begin{array}{l}\text { No of } \\
\text { pods } \\
\text { plant }^{-1}\end{array}$} & $\begin{array}{l}\text { Pod } \\
\text { length } \\
(\mathrm{cm})\end{array}$ & $\begin{array}{l}\text { No of } \\
\text { seeds } \\
/ \text { pod }^{-1}\end{array}$ & $\begin{array}{l}100 \text { seed } \\
\text { wt. }(\text { gm) }\end{array}$ & $\begin{array}{l}\text { Pla } \\
\text { weig } \\
\text { (gm }\end{array}$ & dry & \multicolumn{2}{|c|}{$\begin{array}{l}\text { Seed Yield } \\
\left(\mathrm{kg} \mathrm{ha}^{-1}\right)\end{array}$} & $\begin{array}{l}\text { Stor } \\
\text { yiel } \\
(\mathrm{kg}\end{array}$ \\
\hline $\begin{array}{l}\text { T1: IPM- } \\
\text { 02-14 }\end{array}$ & 46.48 & \multicolumn{2}{|c|}{4.40} & \multicolumn{2}{|c|}{19.20} & 6.99 & 10.34 & 3.65 & & 84 & \multicolumn{2}{|c|}{748} & \\
\hline $\begin{array}{l}\text { T2: Local } \\
\text { (Check) }\end{array}$ & 51.38 & \multicolumn{2}{|c|}{5.60} & \multicolumn{2}{|c|}{16.00} & 6.52 & 10.42 & 2.46 & & 66 & \multicolumn{2}{|c|}{553} & \\
\hline \multicolumn{14}{|c|}{ Table.3 Yield performance of green gram under farmers' practice and front line demonstration } \\
\hline \multicolumn{3}{|c|}{ Treatments } & \multicolumn{2}{|c|}{$\begin{array}{l}\text { Yield } \\
\left(\mathrm{Kg} \mathrm{ha}^{-1}\right)\end{array}$} & \multicolumn{2}{|c|}{$\begin{array}{l}\text { Standard } \\
\text { Deviation }\end{array}$} & $\mathrm{CV} \%$ & \multicolumn{2}{|c|}{$\begin{array}{l}\% \text { increase over } \\
\text { local check }\end{array}$} & \multicolumn{2}{|c|}{ ' $z$ ' value } & \multicolumn{2}{|c|}{$\mathrm{P}$ value } \\
\hline \multicolumn{3}{|c|}{$\begin{array}{l}\text { Farmers Practices (local } \\
\text { check) }\end{array}$} & \multicolumn{2}{|c|}{553} & \multicolumn{2}{|c|}{0.447} & 8.08 & \multicolumn{2}{|l|}{-} & & & & \\
\hline \multicolumn{3}{|c|}{ Demonstration (IPM -02-14) } & \multicolumn{2}{|c|}{748} & \multicolumn{2}{|c|}{0.310} & 4.153 & \multicolumn{2}{|l|}{35.2} & \multicolumn{2}{|c|}{$27.48299 *$} & \multicolumn{2}{|c|}{0.00001} \\
\hline
\end{tabular}

$*$ indicates significance of value at $\mathrm{P}=0.05$. Critical value two-tail $(\mathrm{z}$ score $)=1.959$

Table.4 Technology gap and technology index of the demonstrated technology

\begin{tabular}{|c|c|c|c|c|}
\hline Yield & $\begin{array}{c}\text { Average Yield } \\
\left(\mathrm{Kg} \mathrm{ha}^{-1}\right)\end{array}$ & $\begin{array}{c}\text { Technology gap } \\
\left(\mathrm{Kg} \mathrm{ha}^{-1}\right)\end{array}$ & $\begin{array}{c}\text { Extension gap } \\
\left(\mathrm{Kg} \mathrm{ha}^{-1}\right)\end{array}$ & $\begin{array}{c}\text { Technology index } \\
(\%)\end{array}$ \\
\hline Farmer's yield & 553 & - & - & - \\
\hline Demonstration yield & 748 & $\mathbf{3 5 2}$ & 195 & 32.0 \\
\hline
\end{tabular}

Table.5 Economics and benefits cost ratio

\begin{tabular}{|l|c|c|c|c|}
\hline \multicolumn{1}{|c|}{ Treatments } & $\begin{array}{c}\text { Cost of } \\
\text { Cultivation } \\
\left(\text { Rs ha }^{-1}\right)\end{array}$ & $\begin{array}{c}\text { Gross Return } \\
\left(\text { Rs ha }^{-1}\right)\end{array}$ & $\begin{array}{c}\text { Net Return } \\
\left(\text { Rs ha }^{-1}\right)\end{array}$ & $\begin{array}{c}\text { Benefit Cost } \\
\text { ratio } \\
\text { (B:C ratio) }\end{array}$ \\
\hline $\begin{array}{l}\text { Demonstration } \\
\text { (IPM-02-14) }\end{array}$ & 18250 & 39270 & 21020 & 2.15 \\
\hline $\begin{array}{l}\text { Farmer's } \\
\text { practice } \\
\text { (Local check) }\end{array}$ & 16350 & 29050 & 12700 & 1.77 \\
\hline
\end{tabular}

Table.6 Area, production and productivity of green gram in Jagatsinghpur district of Odisha

\begin{tabular}{|l|l|l|l|l|l|l|}
\hline Crop & \multicolumn{3}{|c|}{ Odisha } & \multicolumn{3}{c|}{ Jagatsinghpur } \\
\hline $\begin{array}{l}\text { Green } \\
\text { gram }\end{array}$ & $\begin{array}{l}\text { Area } \\
(000 \text { 'ha })\end{array}$ & $\begin{array}{l}\text { Production } \\
(\text { (000MT) })\end{array}$ & $\begin{array}{l}\text { Productivity } \\
\left(\mathrm{kg} \mathrm{ha}^{-1)}\right.\end{array}$ & $\begin{array}{l}\text { Area } \\
(000 \text { 'ha })\end{array}$ & $\begin{array}{l}\text { Production } \\
(\text { 000MT })\end{array}$ & $\begin{array}{l}\text { Productivity } \\
\left(\mathrm{kg} \mathrm{ha}^{-1)}\right.\end{array}$ \\
\hline
\end{tabular}


Fig.1 Blockwise area of Green gram in Jagatsinghpur district (2015-16)

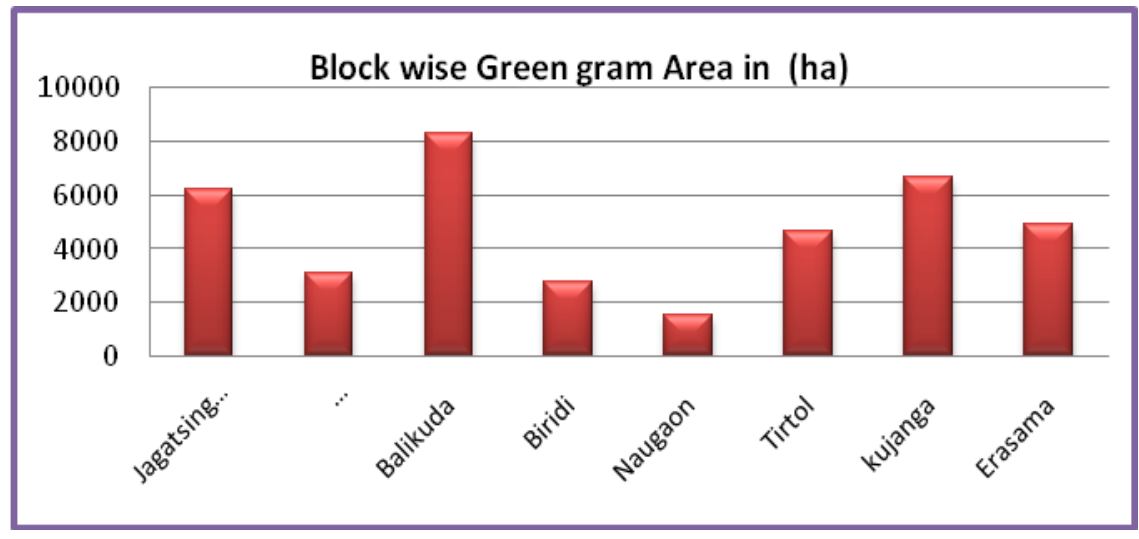

\section{Technology gap}

The technology gap is the difference or gap between the demonstration yield and potential yield (1100 kg/ha) and it was $352 \mathrm{~kg} / \mathrm{ha}$. This gap exists due to variation in the soil fertility and climatic conditions. Hence location specific recommendations are necessary to bridge the gap. These findings are similar to the findings of Patel et al., (2013) (Table 4).

\section{Technology index}

Technology index shows the feasibility of the technology at the farmer's field. The lower the value of technology index more is the feasibility. Result of present study depicted in Table 2, revealed that the technology index values were $32.0 \%$.

The economics of the green gram production under demonstrations and farmers practices have been presented in Table 5 .

The results of economics analysis of green gram production revealed that the gross expenditure in case of IPM -02 -14 was higher than Farmer's variety (Local check). The HYV green gram under demonstration recorded gross return and net profit of Rs. 39270 ha $^{-1} \&$ Rs 21020 ha $^{-1}$, respectively. The local variety under farmers practice had gross return and net profit of Rs. $29050 \mathrm{ha}^{-1}$ and Rs $12700 \mathrm{ha}^{-1}$. The benefit cost ratio (B:C ratio) in demonstration was 2.15 which is higher than farmers practice, 1.77. It is due to higher yield of the demonstrated variety under recommended package of practices. These findings are similar with findings of Patel $e t$ al., (2013) and Samant (2014)

The findings of the study revealed that wide gap exist in demonstration yield and farmers practice in green gram varieties due to technology and extension gap in Jagatsinghpur District of Odisha (Table 6). The per cent increment in yield of green gram to the extent of $35 \%$ in FLDs over the farmers practice created greater awareness and motivated the other farmers to adopt the improved package of practices of green gram. Yield improvement in green gram is due to combined effect of high yielding variety, balanced application of nutrients and application of bio fertilizer like seed inoculation with Rhiozobium and PSB application and adoption of improved plant protection measures. The recipient farmers of FLDs also play an important role as source of information and quality seeds for wider dissemination of the improved varieties of green gram for other nearby farmers. It is concluded that the FLD programme is a successful tool in enhancing the production 
and productivity of green gram crop. Green gram yield potential can be increased to great extent by conducting effective front line demonstration with proven technologies.

\section{References}

Kataria, A., Chauhan, B.M. and Punia, D. 1989. Anti- nutrients and protein digestibility (in vitro) of mung bean as affected by domestic processing and cooking. Food Chem., 32:9-17

Lalit M. Patil, D. J. Modi, H. M. Vasava, S. R. Gomkale 2015. Evaluation of Front Line Demonstration Programme on Green gram Variety Meha (IPM-99125) in Bharuch district of Gujarat, IOSR Journal of Agriculture and Veterinary Science (IOSR-JAVS), Volume 8, Issue 9, PP 01-03, www.iosrjournals.org

Malik, A., Fayyaz-Ul-Hassan, A., Abdul Wahieed, A., Qadir, G. and Asghar, R. 2006. Interactive effects of irrigation and phosphorus on green gram (Vigna radiata L.). Pakistan J. Bot., 38(4): 1119-1126.

Patel, H.R., Patel, F.H., Maheriya, V.D and Dodia, I.N 2013. Response of Kharif green gram (Vigna radiate L.) to Sulphur and Phosphorus with and without biofertilizer application. Bioscan, 8(1): 149-152.
Raj, A.D. Yadav, V. and Rathod J.H. 2013. Impact of Front Line Demonstrations (FLD) on the yield of pulses. International Journal of Scientific and Research Publications, Volume 3, Issue 9, September 2013

Raja D, Kalakarni M K, Janaki P. 2009. Performance of front line demonstration on green gram and black gram in Salem district of Tamil Nadu, India, Agriculture update, vol4, issue 172, pp 17-19

Reddy, A.A. 2010. Regional Disparities in Food Habits and Nutritional intake in Andhra Pradesh, India, Regional and Sectoral Economic Studies Vol. 10-2.

Samant, T.K. 2014. Evaluation of growth and yield parameters of green gram (Vigna radiata L.). Agric. Update, 9(3): 427430.

Singh R, Sharma A. K., Singh S.P. 2012. Agricultural Statistics, Test of significance. Aman Publishing House Meerut, UP, pp196-245.

Venkatasubramanian, V., Sajeev M.V., Singha A. K. 2010. Concept, Approaches and Mythologies for Technology Application and Transfer, ICT led Knowledge management in KVKs, The Zonal Project Directorate Zone -III, ICAR, Umiam, Meghalaya Chapter -IX. Pp. 85-86.

\section{How to cite this article:}

Dash, S.R., B.K. Rautaray and Dhal, A. 2018. Perception and Constraints faced by Pulse Growers and yield gap analysis of Green Gram (Vigna radiata L.) in East and South East Coastal Plain of Odisha, India. Int.J.Curr.Microbiol.App.Sci. 7(01): 338-346. doi: https://doi.org/10.20546/ijcmas.2018.701.038 